\title{
Analysis of Accruals Quality on the Cost of Capital - A Case Study on Manufacturing Companies in Indonesia
}

\author{
EMY ROSIANA SWANDEWI CANDRA \\ ERNI EKA WATI* \\ Universitas Kristen Duta Wacana
}

\begin{abstract}
This study analyzes the effect of accruals quality on the cost of capital. Cost of capital consists of the cost of debt and cost of equity. Accrual quality is influenced by several factors which are divided into two groups: non-discretionary accruals (innate) and discretionary accruals. The sample used in this study is manufacturing companies listed in Indonesia Stock Exchange from the period of 2002 to 2013. Ordinary least square linear regressions are employed to analyze the data. The results showed that the quality of accruals negatively affects the cost of capital. However, the cost of capital of manufacturing companies in Indonesia is not affected by the innate accruals quality but only affected by the quality of discretionary accruals. The study suspects that investors may not be known to the practice of earnings management that affects accrual quality in reported earnings.
\end{abstract}

Keywords: Accruals Quality, Discretionary Accruals, Non-Discretionary Accruals, Cost of Debt, Cost of Equity.

Intisari: Penelitian ini menganalisis pengaruh kualitas akrual pada biaya modal. Biaya modal terdiri dari biaya utang dan biaya ekuitas. Kualitas akrual dipengaruhi oleh beberapa faktor yang dibagi menjadi dua kelompok: non-discretionary accruals (bawaan) dan akrual diskresioner. Sampel yang digunakan dalam penelitian ini adalah perusahaan manufaktur yang terdaftar di Bursa Efek Indonesia dari periode 2002 hingga 2013. Regresi linier terkecil biasa digunakan untuk menganalisis data. Hasil penelitian menunjukkan bahwa kualitas akrual berpengaruh negatif terhadap biaya modal. Namun, biaya modal perusahaan manufaktur di Indonesia tidak dipengaruhi oleh kualitas akrual bawaan, tetapi hanya dipengaruhi oleh kualitas akrual diskresioner. Studi ini mencurigai bahwa investor mungkin tidak memiliki pengetahuan tentang praktik manajemen laba yang mempengaruhi kualitas akrual dalam laba yang dilaporkan.

Kata kunci: Kualitas Akrual, Akrual Diskresioner, Akrual Non-Discretionary, Biaya Utang, Biaya Ekuitas.

* Corresponding author: ekawati.erni@gmail.com 


\section{Introduction}

Recent empirical works on capital assets pricing show that information risk is a non-diversified risk factor that is priced in the capital market. Using quality of accounting accruals as proxies for information risk, Francis et al. (2005) and Gray et al. (2009) provided empirical supports using a sample of the US and Australian firms, respectively. This study re-examines the relation between accruals quality and cost of capital in Indonesia, where non-discretionary and discretionary accruals are hypothesized to affect the cost of capital. The result suggests that, while accruals quality impacts on the cost of capital for manufacturing firms in Indonesia, some variety of differences exist. In contrast to findings for Australian firms (Gray et al., 2009), the costs of debt and equity for Indonesian firms are primarily influenced by accruals quality arising from discretionary reporting choicesbut, not economic fundamentals. However, the findings for Indonesian firms are similar to those of Francis et al. (2005) for the US firms. The study suspects that Indonesian investors may not be known to the practice of earnings management that affects accrual quality in reported earnings.

Financial statements are a structured representation of the financial position and financial performance of an entity. The financial statements have the purpose in providing information concerning the financial position, performance as well aschanges in the financial position of an enterprise that will givebenefits toa large number of users in making economic decisions. The broader the disclosure of financial statements by management, the more transparent the company. Types of financial statement reporting consist of cash and accrual basis. However, the cash basiswill be limited in their usefulness if a company has a lot of long-term investments. Information of earnings contained in the financial statement is one of the essential elements used in an investment decision. Transparent reporting of earnings is required for public companies. The reported earnings quality is high if it is useful for investors to predict the stock price and returns for investment decision purposes. Earnings information in financial statements reported using the accrual-basis will provide an 
opportunity for management to maximize their utility in discretionary accrual reporting choices.

Givoly et al. (2010) mentioned that the quality of accruals indicates the quality of earnings. Companies with low accruals show high earnings quality because there is a tendency of corporate managers using accruals to perform actions with the purpose of reporting higher profits through earnings management practices. Managers have choices in reporting accruals and rights to greater access to internal information compared with shareholders or investors. Accruals that are resulted from managers' discretionary choices are called discretionary accruals, while those of resulted as consequences fundamental economic discretions are non-discretionary accruals or the so-called innate accruals.

Companies require capital to invest and expand their business. The source of capital can be achieved internally and externally, with some specific cost of capital according to the risks embedded in the projects being invested in. The capital costs incurred by the company are closely related to the risk of interpreting financial information provided by managers. The smaller the asymmetry of information that occurs between managers and shareholders or other stakeholders, the smaller the capital costs are born by the company (Ifonie, 2012). Therefore, managers should make the financial information provided to investors to be precise and transparent, to give a useful quality of information for an investment decision. Based onthe theory of assets pricing, companies with lower capital costs, are likely to be faster in restoring return, because of their capital costs minimization to generate maximum returns on capital. The capital costs are the sum of cost composition of debt and equity capital. Theoretically, the more extensive disclosure level of financial reporting, the lower the cost of capital, both debt capital costs (cost of debt) and equity capital costs (cost of equity). Francis et al. (2005) stated that the worse the accrual quality, it means the higher the cost of debt and cost of equity. Thus, the company should pursue a better accruals quality is to minimize its cost of capital. Companies with the high quality of accruals can reduce the asymmetry of information between managers and shareholders along with any other users of financial information. 
This study re-examines Gray et al. (2009) study which observes and analyzes the interaction of accrual quality, information risk and cost of capital in Australia. The results showed that accrual quality has impacts on the cost of capital for Australian companies. The cost of debt and equity for the Australian companies are highly influenced by the quality of accruals arising from economic fundamentals (innate accruals quality) but not from the choice of discretionary reporting (discretionary accruals quality). The study of Gray et al. (2009) based on the research conducted by Francis et al. (2005) reported that non-discretionary and discretionary accruals significantly affect the cost of debtusing sample of Australian firms, non-discretionary accruals quality dominates the effect on the quality of the debt accrued, while the quality of discretionary accruals tend to have a negligible effect. Therefore, it is worth to study the same issues in Indonesia, in which whether the relational behavior of cost of capital and accruals quality is somewhat similar to that of the Australian firms (Gray et al., 2009) or the US firms (Francis et al., 2005). By conducting this study, the analysis can be done to obtain investors' points of view on the importance of accruals quality on financial reporting.

Prior researches usually examine the relationship either between information asymmetry and the cost of capital or the accrual quality and information asymmetry. This study would like to show further research on the relationship between the quality of accruals and the cost of capital based on research done by Gray et al. (2009) as well as analyze whether accruals quality (non-discretionary or discretionary) affects more strongly on the cost of capital. This study differs from Gray et al. (2009) mainly on the object and periods of study. This study employs manufacturing companies listed in Indonesia Stock Exchange during the periods from 2002 to 2013. The objective is directed toward providing empirical evidence on the assets pricing test related to the cost of capital components by using a risk factor that is reflected in the quality of accounting information. 


\section{Theoretical Framework and Hypothesis Development}

Financial statements must provide timely and accurate information to investors for making investment decisions. If the information issued by the management contains self-individual interest purpose, asymmetric information will exist between managers and investors. This asymmetric information will cause risk on the users of financial information, which is called an information risk factor. The higher the asymmetrical information, the higher the information risk factor, which increases the cost of capital of the companies. Therefore, there should be mechanisms that can lower the cost of capital by reducing the risk of information asymmetry, by increasing the accrual quality of corporate financial reporting.

Gray et al. (2009) and Francis et al. (2005) found that the higher the quality of accruals, the lower the risk of information, which results in the lower cost of capital. Consistent with this argument, Francis et al. (2005) have provided evidence that US companies with poor accruals quality have a higher cost of capital (debt and equity). It can be concluded from the results reported by Francis et al. (2005) and Gray et al. (2009) that the quality of accruals negatively affects the cost of capital. The study found that if the quality of accrual is low, due to the high risk of corporate information, it leads to higher capital cost. Conversely, if accrual quality is high, it leads to low capital costs, because the information risk factor of the company is low. Thus, research hypotheses can be stated as follows:

H1a: Quality of accruals negatively affects the cost of debt.

H1b: Quality of accruals negatively affects the cost of equity.

The two sources of the risk of information are coming from environmental/fundamental factors and nature of the company's business. The same way, accruals quality is also derived into a quality that comes from non-discretionary accruals and discretionary accruals. Following Gray et al. (2009) study that is based on research conducted by Francis et al. (2005), accruals quality can be affected by either economic fundamentals (non-discretionary accruals/innate) or management reporting policies and choice (discretionary accruals). The study is based on research conducted 
by Guay et al. (1996), which derives the accruals into three components which are performance, opportunism and pure noise. Performance component reflects management's ability to increase earnings following the actual performance of the company. Pure noise is the error component that cannot be explained in assessing the quality of discretionary accruals, while opportunism component reflects the opportunistic behavior of the various parties that make financial statements not align with the company's performance. In this case, when the quality of the accruals is affected by the innate or non-discretionary factors, it can reduce the information risk because this factor is based on the state of economic fundamentals and not intentional. If the quality of the accruals is affected by discretionary factors, it leads to increasethe information risk.

Guay et al. (1996)stated that the components of accruals might have an offsetting effect on the information risk that is when the manager is trying to make financial statements following the actual state of the company's performance, and there are other managers attempting to manipulate the financial statements for particular interests. Thus, the non-discretionary and discretionary components of accruals could offset one another on their influence on the information risk in affecting the company's cost of capital.

Francis et al. (2005) and Gray et al. (2009) then expect that discretionary accruals quality have a smaller effect compared to the non-discretionary accruals quality (innate) on the information risk factor. In line with their results, this research will examine the influence of non-discretionary accruals quality (innate) and discretionary accruals quality against the cost of capital. The following hypotheses are built on the assumption that investors have sufficient knowledge of the quality of financial statements that are reflected in their accruals.

H2a: Non-discretionary accruals quality (innate) has a more significant effect than discretionary accruals quality on the cost of corporate debt.

H2b: Non-discretionary accruals quality (innate) has a more significant effect than discretionary accruals quality on the cost of equity. 


\section{Research Method}

\subsection{Data Selection and Sample}

The data used in this research is secondary data drawn from the Indonesia Stock Exchange. Sample data used are the companies listed in the manufacturing sector from the periods of 2002 to 2013. The sample is selected by using purposive sampling method, based on a set of criteria. Since this study employs Gray et al. (2009) model, based on the accruals model developed byDechowandDichev (2002) and modified by McNichols (2002) and Francis et al. (2005), the sample requires complete time series financial statement data. Research sample selection criteria are manufacturing companies:

1. Listed on the Indonesia Stock Exchange from the periods 2002 to 2013,

2. That have financial statements denominated in rupiah, and

3. Thathave a complete financial statement data from the year 2002 to 2013 .

Variables Definition of Accruals Quality (TAQrank), Innate Accruals Quality (InnAQrank) and Discretionary Accruals Quality (DisAQrank).

This study consists of two types of variable, namely the quality of accruals as independent variables and capital costs (cost of capital) as dependent variables. Measuring the quality of accruals is first proposed by Jones (1991) and then modified by Dechow and Dichev (2002) by making some adjustments on credit sales. The model of Dechow and Dichev (2002) is then further developed by McNichols (2002) and Francis et al. (2005). The latest model is employed by Gray et al. (2009) in their study by using decile rank method to estimate accruals quality, innate accruals quality as well as the quality of discretionary accruals.

Mc Nichols (2002), Francis et al. (2005) models and decile rank method of Gray et al. (2009) are combined to estimate accruals quality. Here is the model used to estimate the quality of accruals. Average total assets divide all variables.

$T C A_{j, t}=\beta_{0}+\beta_{1} C F O_{j, t-1}+\beta_{2} C F O_{j, t}+\beta_{3} C F O_{j, t+1}+\beta_{4} \Delta R E V_{j, t}+\beta_{5} P P E_{j, t}+\mu_{j, t}$ 
Total current accruals (TCA) are computed with the following formula.

$T C A_{j, t}=\Delta C A_{j, t}-\Delta C L_{j, t}-\Delta \operatorname{Cash}_{j, t}+\Delta S T D e b t_{j, t}$

where,

TCA: Total current accruals

$\triangle \mathrm{CA}$ : Change in current assets from year $\mathrm{t}-1$ to year $\mathrm{t}$

$\Delta \mathrm{CL}$ : $\quad$ Change in current liabilities from year t-1 to year $\mathrm{t}$

$\Delta$ Cash: Change in cash from year t 1 to year $\mathrm{t}$

$\Delta$ STDebt: $\quad$ Change in debt in year $\mathrm{t}-1$ and $\mathrm{t}$

CFO: $\quad$ Operating cash flow

$\triangle \mathrm{REV}$ : $\quad$ Change in revenue from year $\mathrm{t}-1$ to year $\mathrm{t}$

PPE: $\quad$ Gross fixed assets

Five industrial groups are consisting of at least ten manufacturing companies that exhibit similarities within one industry. All residuals of each industry group are tested using regression equation (1) of residuals generated from each industry group, each company's standard deviation of the residuals within the period of the last five years is computed. Moreover, a decile rank value is determined by rating raw accrual quality per year, from the highest to the lowest value. The group with the highest accruals value is rated of rank 1 in decile, while that of with the lowest one is rated of rank 10 in decile. Rank of the standard deviation is called TAQrank which reflects the quality of the accruals each year. Rank 1 reflects the lowest quality, while rank 10 reflects the highest quality.

$$
\begin{aligned}
\operatorname{TAQrank}_{j, t}= & \Phi_{0}+\Phi_{1} \operatorname{SIZE}_{j, t}+\Phi_{2} \sigma(C F O)_{j, t}+\Phi_{3} \sigma(S A L E S)_{j, t}+\Phi_{4} O p C y c l e_{j, t}+ \\
& \Phi_{5} \operatorname{NegEarn}_{j, t}+v_{j, t}
\end{aligned}
$$

where,

TAQrank: The standard deviation of the residual regression of TCA equation SIZE: $\quad$ Natural log of total assets 
$\sigma(\mathrm{CFO})$ : $\quad$ Standard deviation of operating cash flow calculated within the last five years

$\sigma$ (Sales): $\quad$ Standard deviation of sales revenue calculated within the last five years

OpCycle: $\quad$ Operating cycle is calculated from the sum of log receivable turnover and inventory turnover

NegEarn: $\quad$ Number of years with negative earnings over the previous five years of data

The predicted value of the equation (3) is used to determine the value of nondiscretionary/innate accruals quality (InnAQrank) while the residual value reflects discretionary accruals quality (DisAQrank). Decile rank value is employed to identify the accruals quality, the decile rank of 1 contains the companies with the lowest quality of accruals, while the decile rank 10 are the companies with the highest quality of accruals. The quality of accruals (TAQrank) could come from the nondiscretionary/innate (InnAQrank) and discretionary accruals (DisAQrank).

\section{Statistical Models for Hypothesis Tests}

To test the research hypothesis of H1A, the following statistical model is used:

$$
\begin{aligned}
\operatorname{COD}_{j, t+1}= & \beta_{0}+\beta_{1} \operatorname{TAQrank}_{j, t}+\beta_{2} \operatorname{SIZE}_{j, t}+\beta_{3} \operatorname{ROA}_{j, t}+\beta_{4} \operatorname{Inv}_{\operatorname{Cov}_{j, t}}+ \\
& \beta_{5} \sigma(N I B E)_{j, t}+\beta_{6} \text { Leverage }_{j, t}+\mu_{j, t}
\end{aligned}
$$

where,

COD: $\quad$ Cost of debt which is calculated from interest expense at period $\mathrm{t}+1$ divided by average total debt within period $\mathrm{t}$ and $\mathrm{t}+1$

TAQrank: Decile rank value of accruals quality

Size: The natural logarithm of total assets calculates the size of the company

ROA: $\quad$ Return on assets is derived from the ratio of net income to total assets 
IntCov: Interest coverage is derived from the ratio of operating profit to interest expense

бNIBE: $\quad$ Standard deviation of net income of the last five years divided by average assets

Leverage: $\quad$ Ratio of total debt to total assets

The hypothesis of H1A is supported when the coefficient of TAQrank, $\beta 1$, on regression equation (4) is negative and significant.

To test the research hypothesis of $\mathrm{H} 1 \mathrm{~B}$, the following statistical model is used:

$$
\begin{aligned}
\operatorname{COE}_{j, t}=\beta_{0}+ & \beta_{1} \text { TAQrank }_{j, t}+\beta_{2} \text { Lev }_{j, t}+\beta_{3} \text { Beta }_{j, t}+\beta_{4} \text { Size }_{j, t}+\beta_{5} \text { Growth }_{j, t} \\
& +\mu_{j, t}
\end{aligned}
$$

where,

COE: The industry-adjusted approach to earnings-price ratio calculates the cost of equity

TAQrank: Decile rank value of the quality of accruals

Lev: The ratio of total debt to total assets

Beta: beta value is calculated by using a regression of weekly stock return companies on stock returns weekly market (JCI)

Size: The natural logarithm of total assets calculates the size of a company

Growth: The log of one plus the value of the book value of the company's growth

The hypothesis of H1B is supported when the coefficient of TAQrank, $\beta 1$, on regression equation (5) is negative and significant.

To test the hypothesis $\mathrm{H} 2 \mathrm{~A}$, namely the influence of innate and discretionary accruals quality on the cost of debt, the following statistical model is employed:

$$
\begin{gathered}
\operatorname{COD}_{j, t+1}=\beta_{0}+\beta_{1} \operatorname{InnAQrank}_{j, t}+\beta_{2} \operatorname{DiSAQrank}_{j, t}+\beta_{3} \operatorname{ROA}_{j, t}+\beta_{4} \operatorname{Inv}_{\operatorname{Cov}_{j, t}}+ \\
\beta_{5} \sigma(N I B E)_{j, t}+\beta_{6} \operatorname{Lev}_{j, t}+\beta_{7} \operatorname{SIZE}_{j, t}+\mu_{j, t}
\end{gathered}
$$


where,

InnAQrank: Decile rank value of innate accruals quality.

DisAQrank: Decile rank value of discretionary accruals quality.

To test the hypothesis $\mathrm{H} 2 \mathrm{~B}$, which is the influence of innate and discretionary accruals quality on the cost of equity, the following statistical model is employed:

$$
\begin{gathered}
\operatorname{COE}_{j, t}=\beta_{0}+\beta_{1} \text { InnAQrank }_{j, t}+\beta_{2} \text { DisAQrank }_{j, t}+\beta_{3} \text { Lev }_{j, t}+\beta_{4} \text { Beta }_{j, t}+ \\
\beta_{5} \text { Size }_{j, t}+\beta_{6} \text { Growth }_{j, t}+\mu_{j, t}
\end{gathered}
$$

To test $\mathrm{H} 2 \mathrm{~A}$ and $\mathrm{H} 2 \mathrm{~B}$, the expected results of InnAQrank coefficients, $\beta 1$ on equation (6) and (7) are negative and significant. The higher the quality of innate accruals will reduce the information risk, then result in the lower both the cost of debt and cost of equity. The expected results of DisAQRank coefficients, $\beta 2$ on equation (6) and (7) are also negative and significant. These results are expected because DisAQrank also reflects the quality of discretionary accruals. However, when comparing the coefficients of InnAQrank and DisAQrank, it is expected that $|\beta 1|>\mid$ $\beta 2 \mid$. This result is expected because the innate accruals quality is expected to have greater influence than the quality of discretionary accruals on both costs of debt and cost of equity.

\section{Results and Analysis}

\subsection{Sample and Descriptive Statistics}

The tests are based on a sample of manufacturing companies listed on the Indonesia Stock Exchange and 6 sample years, 2007-2013. Since some variables need time series computation of standard deviation for five prior years, the data for years preceding 2002 are employed. The final sample comprises 186 firm-year observations for 31 firms, and the data requirements are described in Table 1 below. 


\section{Table 1.}

Sample Criteria for Testing Hypothesis - H1a, H1b, H2a, and H2b

\begin{tabular}{lcc}
\hline \multicolumn{1}{c}{ Sample Criteria } & $\begin{array}{c}\text { H1a and } \\
\text { H2a }\end{array}$ & H1b andH2b \\
\hline Manufacturing firms listed in 2002- 2013 & 98 & 98 \\
Firms using non-rupiah currency denomination & $(8)$ & $(8)$ \\
Firms with no complete data & $(33)$ & $(33)$ \\
Firms with financial data outliers & $(26)$ & $(32)$ \\
Number of firms & 31 & 25 \\
Number of years for data analysis (2007-2012) & 6 & 6 \\
Firms-years final observations & 186 & 150 \\
\hline
\end{tabular}

Table 2 and 3 present descriptive statistics for the variables used in all regression equations and hypothesis tests. The statistical description of the sample shows that the distribution of data in each variable is within the range value of fewer than 8 times standard deviation. Overall distributional statistics variables for testing the hypothesis $\mathrm{H} 1 \mathrm{~A}$ and $\mathrm{H} 2 \mathrm{~A}$ are shown in Table 2, while the statistical distributions for variables to test hypothesis $\mathrm{H} 2 \mathrm{~A}$ and $\mathrm{H} 2 \mathrm{~B}$ are presented in Table 3.

The mean values of TAQrank, InnAQrank, and DisAQrank, as shown in Table 2, are 5,973; 5,960; and 5,620 respectively. These values indicate that the accruals quality is above the average values of the decile rank. Similar amount and distribution are also indicated in Table 3. Thus, sample data on accruals quality show that financial statements of manufacturing firms listed in Indonesia Stock Exchange have a somewhat big proportion on accruals. A large amount of accruals meets the requirement for this study to analyze the source of accruals that influences the company's cost of capital. 
Table 2.

Descriptive Statistics for Testing Hypothesis H1a and H2a

\begin{tabular}{lrrrr}
\hline & Minimum & \multicolumn{1}{c}{ Maximum } & \multicolumn{1}{c}{ Mean } & Standard Deviation \\
\hline COD & 0.002 & 0.260 & 0.010 & 0.057 \\
TAQrank & 1.000 & 10.000 & 5.973 & 2.884 \\
InnAQrank & 1.000 & 10.000 & 5.960 & 3.111 \\
DisAQrank & 1.000 & 10.000 & 5.620 & 2.844 \\
Size & 24.560 & 32.840 & 28.168 & 1.713 \\
ROA & -0.140 & 0.470 & 0.089 & 0.097 \\
IntCov & -2.970 & 701.130 & 46.076 & 92.496 \\
$\sigma 2.49$ & 0.005 & 0.465 & 0.045 & 0.056 \\
Lev & 0.010 & 1.030 & 0.475 & 0.241 \\
$\mathrm{~N}$ & 186 & & & \\
\hline
\end{tabular}

Table 3

Descriptive Statistics for Testing Hypothesis H1B and H2B

\begin{tabular}{lrrrr}
\hline & Minimum & \multicolumn{1}{c}{ Maximum } & \multicolumn{1}{c}{ Mean } & Standard Deviation \\
\hline COE (INDEP) & -0.743 & 0.461 & 0.015 & 0.147 \\
TAQrank & 1.000 & 10.000 & 6.190 & 2.638 \\
InnAQrank & 1.000 & 10.000 & 5.110 & 3.154 \\
DisAQrank & 1.000 & 10.000 & 6.510 & 2.659 \\
Lev & 0.040 & 0.990 & 0.444 & 0.219 \\
Beta & -0.680 & 1.160 & 0.421 & 0.392 \\
Size & 24.560 & 31.360 & 27.694 & 1.623 \\
Growth & 4.250 & 10.300 & 6.703 & 1.534 \\
$\mathrm{~N}$ & 150 & & & \\
\hline
\end{tabular}




\subsection{Statistical Test Results}

Equation (4) and (5) are used to test hypothesis $\mathrm{H} 1 \mathrm{~A}$ and $\mathrm{H} 1 \mathrm{~B}$, and the results show that TAQrank regression coefficients are -0.004 and -0.016 , which are significant with the alpha level of $5 \%$ and $1 \%$, respectively (See Table 4 and 5). Thus, $\mathrm{H} 1 \mathrm{~A}$ and $\mathrm{H} 1 \mathrm{~B}$ are supported. The higher the quality of accruals the lower the COD (cost of debt) and $\mathrm{COE}$ (cost of equity). The other variables in the equations are considered as control variables being included in the models to make the relationship between TAQrank and cost of capital clean from the other possible influencing factors.

Table 4

Results of Hypothesis Tests on COD

\begin{tabular}{lcccc}
\hline & \multicolumn{2}{c}{ H1A } & \multicolumn{2}{c}{ H2A } \\
\cline { 2 - 5 } & Coefficients & T Test & Coefficients & T Test \\
\hline Constant $)$ & $0.371^{* * *}$ & 6.009 & - & 6.214 \\
TAQrank & $-0.004 * *$ & -2.298 & - & - \\
InnAQrank & - & - & 0.001 & 0.006 \\
DisAQrank & - & - & $-0.239 * * *$ & -2.938 \\
Size & $-0.009 * * *$ & -4.113 & $-0.411^{* * *}$ & -4.460 \\
ROA & $0.186^{* * *}$ & 2.973 & $0.306 * * *$ & 2.871 \\
IntCov & $0.000^{* * *}$ & -5.087 & $-0.404 * * *$ & -4.398 \\
$\sigma \mathrm{NIBE}$ & $-0.191 * * *$ & -2.788 & $-0.210^{* * * *}$ & -2.960 \\
Lev & $0.053 * *$ & 2.270 & $0.266 * *$ & 2.596 \\
Adj $R^{2}$ & 0.269 & & & \\
\hline
\end{tabular}

*** $\quad:$ significant at level1\% $\quad * * \quad:$ significant at level $5 \%$ 
Table 5

Results of Hypothesis Tests on COE

\begin{tabular}{lcccc}
\hline \multicolumn{2}{c}{ H2A } & \multicolumn{2}{c}{ H2B } \\
\hline Coefficients & T Test & Coefficients & T Test \\
\hline TAQrank & 0.546 & 2.769 & - & 3.312 \\
InnAQrank & $-0.016^{* * *}$ & -3.344 & - & - \\
DisAQrank & - & - & 0.069 & 0.543 \\
Lev & - & - & $-0.261^{* * *}$ & -2.873 \\
Beta & $-0.298^{* * *}$ & -5.312 & $-0.333^{* * *}$ & -3.874 \\
Size & $0.066 * *$ & 2.211 & $0.160 * *$ & 1.991 \\
Growth & -0.013 & -1.734 & $-0.370^{* * *}$ & -2.766 \\
& 0.003 & 0.351 & 0.052 & 0.683
\end{tabular}

$\operatorname{Adj} R^{2}$

Table 4 and 5 also show the results of the hypothesis test of $\mathrm{H} 2 \mathrm{~A}$ and $\mathrm{H} 2 \mathrm{~B}$ employing equation (6) and (7), respectively. The regression coefficients of InnAQrank on COD and COE are 0,001 and 0.069, respectively and not statistically significant. These regression results do not show any evidence of the relationship between InnAQrank and the cost of capital. However, the regression coefficients of DisAQrank on COD and COE are statistically significant at a level alpha of $1 \%$, with the amount of $-0,239$ and $-0,261$, respectively. These results indicate that the higher the DisAQrank, the lower the COD and COE. Hypothesis H2A and H2B are tested by comparing two regression coefficients of InnAQrank and DisAQrank on both COD and COE. The results indicate that the coefficient ofDisAQrankis more prominently affect both the COD and COE. Thus H2A and H2B are not supported in the sense that the coefficient of InnAQrankhas no more significant impact than that ofDisAQrankon the COD and COE. Model on equation (6) and (7) also has been controlled by some 
other factors that possibly influence the COD and COE. The other factors that affect the COD are Size, ROA, IntCov, $\sigma \mathrm{NIBE}$, and Lev, while the factors affect the COE are Lev, Beta, Size, and Growth.

\subsection{Analysis}

The results of the study support Hypothesis H1A and H1B that accruals quality negatively affect the cost of capital both for the cost of debt and cost of equity. This finding is in line with prior researches done by Francis et al. (2005). As consequences, the companies with lower accruals quality produce higher capital costs (cost of debt and cost of equity) than firms with higher accruals quality. The results also support the Gray et al. (2009) providing empirical evidence that the higher the quality of accruals, the lower the risk of information and resulting in lower cost of equity capital. Investors well recognize total accruals (TAQrank) as a measure of quality accruals. These accruals can give rise to the information risk due to the increased chance of asymmetric information induced by a large amount of accruals in financial statements.

The hypothesis $\mathrm{H} 2 \mathrm{~A}$ and $\mathrm{H} 2 \mathrm{~B}$ are tested by decomposing TAQrank (total accruals) into innate/non-discretionary (InnAQrank) and discretionary accruals (DisAQrank). The results indicate that the innate/non-discretionary accruals do not affect the cost of capital, both for the cost of debt and cost of equity. These findings are somewhat surprising, that the investors might not see the accruals that cause the change of the company's performance coming from the fundamental economic values. On the contrary to these results, the discretionary accruals quality even affects the cost of capital in the right direction. The discretionary accruals quality can reduce the cost of capital for both costs of debt and cost of equity. When the cost of capital is priced in the capital market for making an investment decision, it will induce stock misspricing, since the discretionary accruals should not be considered in pricing. The source of information risk factors in Indonesia Capital Market indicated from this study, comes from the accruals which are not fundamentally having economic values.

These results do not support the prior studies done by Francis et al. (2005) and Gray et al. (2009), namely that the quality of discretionary accruals are less 
influencing than the quality of non-discretionary (innate) accruals on the risk of information that has towards the cost of capital. Francis et al. (2005) say that the component of discretionary accruals reflects the quality of the management policy options, for example in the form of earnings management practices to manipulate the company's earnings in the reporting of financial statements. This study indicates profound earnings management practices in manufacturing companies, because the quality of discretionary accruals has a significant effect, while the innate accruals quality does not have a substantial effect on the cost of capital.

Also, investors cannot interpret earnings management in the company very well that investors do not realize that earnings management practices carried out by the issuer. This is reinforced by Lambert et al. (2007) study on the international comparison of earnings management practices and investor protection. The study reports that Indonesia is a country with the highest level of earnings management practices compared to other ASEAN countries namely Malaysia, Philippines, and Thailand.

\section{Conclusions, Implications, and Limitations}

\subsection{Conclusions}

This study aims to examine the influence of the accrual quality on the capital cost of manufacturing companies listed in Indonesia Stock Exchange from 2003 until 2013. Ordinary least square linear regressions are employed to analyze the data. Two regression equations are used to test the accruals quality on the cost of capital which is divided into the cost of debt and cost of equity, while the next two equations are used to test the quality of non-discretionary accruals (innate) and discretionary accruals quality on the capital cost of debt and cost of equity. Based on the analyses and discussions, this study concludes that: a). Accruals quality affect the cost of debt. The regression coefficient is negative, which means the higher the quality of accruals, the lower the companies' cost of debt. The results are consistent with prior researches conducted by Francis et al. (2005) and Gray et al. (2009); b). Accruals quality affect the cost of equity capital. The regression coefficient is negative, which means the 
higher the quality of accruals, the lower the companies' cost of equity capital. The results of this study are also consistent with studies conducted by Francis et al. (2005) and Gray et al. (2009); c). In the study, only the quality of discretionary accruals that affect the cost of capital (debt and equity), whereas no influence of non-discretionary accruals (innate) is found on the cost of capital (debt and equity) of the company. Thus the effect of discretionary accruals quality is more profound than non-discretionary accruals on the cost of capital. The results of this study do not correspond to previous studies conducted by Francis et al. (2005) and Gray, et al. (2009).

\subsection{Implications}

Based on the statement of Francis et al. (2005) concerning the predominant factors of discretionary accruals, it is presumably because the manufacturing companies in Indonesia practice earnings management to manipulate the company's profit in the reporting of financial statements. Investors might not well recognize these earnings management practices which are indicated by the predominant accruals quality that induces information risk factors that have towards the cost of capital. If this is the case than the stock prices of manufacturing companies might be miss-priced with the amount of un-diversified information risk factors which are priced in the capital market.

\subsection{Limitations}

Future studies are expected to use a sample of all companies listed on the Indonesia Stock Exchange, as well as the use of a longer study period. The study has a limited answer on the implication of profound discretionary accrual quality influence on the cost of capital. Further studies are expected to deepen in exploring the amount of discretionary accruals embedded on information risk factors that are priced based on the capital asset pricing model.

\section{References}

Dechow, P. M., R. G. Sloan, and A. P. Sweeney. 1995. Detecting earnings management. The Accounting Review 70 (2): 193-225. 
Dechow, P and I. Dichev. 2002. The quality of accruals and earnings: The role of accrual estimation errors. The Accounting Review 11 (Supplement): 35-59.

Easley, D. and M. O'Hara. 2004. Information and the Cost of Capital.Journal of Finance 59 (4): 1553-1583.

Francis, J., R. Lafond, P. Olsson, and K. Schipper. 2004. Cost of Equity and Earning attributes. The Accounting Review 79: 967-1010.

Francis, J., R. Lafond, P. Olsson, and K. Schipper. 2005. The Market Pricing of Accruals Quality. Journal of Accounting and Economics 39 (2): 295-327.

Ghozali, Imam. 2011. AplikasiAnalisis Multivariate Dengan Program IBM SPSS 19. Semarang: BadanPenerbitUniversitasDipenogoro.

Gitman, Joehnk. 2005. Principle of Managerial Finance $11^{\text {th }}$ edition. United States: Pearson Education, Inc.

Givoly, D., C. Hayn and Katz, P. Sharon. 2010. Does Public Ownership of Equity Improve Earnings Quality?. The Accounting Review85 (1): 195-225.

Gray, P., Koh Ping-Sheng, and Tong Yen H. 2009. The Accruals Quality, Information Risk, and Cost of Capital: Evidence from Australia. Journal of Business Finance and Accounting 36 (1-2): 51-72.

Guay, W., S.P. Kothari and R. Watts (1996), 'A Market-Based Evaluation of Discretionary Accruals Models', Journal of Accounting Research, Vol. 34 (supplement), pp. 83-105.

Ifonie, Regina Reizky. 2012. Pengaruh Asimetri Informasi Dan Manajemen Laba terhadap Cost of Equity Capital pada perusahaan Real Estate yang Terdaftar di Bursa Efek Indonesia. Jurnal Ilmiah Mahasiswa Akuntansi 1 (1).

Ikatan Akuntansi Indonesia (IAI). 2009. Pernyataan Standar Akuntansi Keuangan. Jakarta: Salemba Empat.

Jones, J. 1991. Earnings Management during Import Relief Investigations. Journal of Accounting Research 29: 193-228.

Lambert, R.A., C. Leuz, and R. Verrecchia. 2007. Information Asymmetry, Information Precision, and the Cost of Capital. Working Paper, the University of Pennsylvania and the University of Chicago.

McNichols, M. 2002. Discussion of The Quality of Accruals and Earnings: The Role of Accrual Estimation Errors.The Accounting Review 11 (Supplement): 61-69.

Sari, Ni PutuAyuPudak. 2014. Faktor-Faktor yang MemengaruhiStruktur Modal pada Perusahaan Non Keuangan yang Terdaftar di Bursa Efek Indonesia tahun 2008-2012. EJurnal Akuntansi Universitas Udayana 7 (1): 33-47. 
Strydom, Maria, Skully, Michael, and Veeraraghavan, Madhu. 2014. Is the Accrual Anomaly Robust to Firm-Level Analysis? International Review of Financial Analysis 34: 157-165.

Tampubolon, Maria S.H. 2012. Pengaruh Kualitas Akrual terhadap Premi Risiko.Skripsi Fakultas Ekonomi Universitas Indonesia.

Teruel, Pedro J., and Solano Pedro M. 2009. Accruals Quality and Corporate Cash Holdings. Accounting and Finance 49: 95-115.

Trining tyas, Irine Ayu and Silvya Veronica Siregar. 2014. Pengaruh Kualitas Akrual Terhadap Biaya Utang dan Biaya Ekuitas: Studi pada Perusahaan yang Terdaftar di Bursa Efek Indonesia Tahun 2005-2011. Simposium Nasional Akuntansi 17.

Wijaya, Anggita Langgeng. 2011. Pengaruh Kualitas Akrual dan Leverage terhadap Cash Holding Perusahaan. Univ 